\title{
THE EFFECT OF TREATIES IN THE MUNICIPAL LAW OF THE PEOPLE'S REPUBLIC OF CHINA: PRACTICE AND PROBLEMS*
}

\author{
Li Zhaojie ${ }^{* *}$
}

1. Introduction

2. The scope of the term Treaty and the treaty-making procedure

2.1. 'Treaties'

2.2. Treaty-making power and procedure

3. Effect of treaties in the Chinese municipal legal order

3.1. Municipal validity of treaties

3.2. Direct application of treaties

3.3. Conflict between treaty law and municipal law

4. Interpretation of treaties

5. Conclusions

\section{INTRODUCTION}

A great number of international treaties concluded or acceded to by the People's Republic of China during the last one to two decades address matters of civil and economic transactions between private parties, protection of human

\footnotetext{
* This paper is based on a previous one, 'Effect of Treaties in Domestic Law: Practice of the People's Republic of China', 16 Dalhousie Law Journal (1993) 62-97.

** Correspondence research fellow, International Law Institute, Peking University, China; SJD candidate, University of Toronto. The author is indebted to Professors R.ST.J.MACDONALD, WANG TIEYA and Ko SWAN SIK for their enthusiastic support and valuable comments. The views rendered in this article reflects those of the author only.
}

Asian Yearbook of International Law, Volume 4 (Ko Swan Sik et al., eds.; 90-411-0872-6 ${ }^{\circledR} 1995$ Kluwer Law International; printed in Great Britain), pp. 185-223 
rights of individuals, and many other aspects of everyday activities in China. ${ }^{1}$ While such treaties are instruments of international law, their objectives can be achieved only if they are effectuated within the Chinese municipal legal order. These recent developments in China's treaty practice have lent increasing prominence to the question concerning the effect of treaties in the Chinese municipal legal order.

Let us assume that a dispute arises from a transaction governed by a provisions of a treaty to which China is a party. In order for the treaty to apply to the settlement of this dispute before a Chinese court, at least the following questions must be answered: Is the treaty valid within the Chinese municipal legal order? If so, is the treaty provision in question applicable in legal proceedings without requiring any further qualifications? Under what conditions is the application of the treaty justified in the Chinese municipal legal order? What is the status of the treaty if confronted with a conflicting municipal norm governing the same transaction? Last but not least, how is the treaty interpreted by the appropriate Chinese judicial authorities?

Except for the general principle according to which a state must fulfill in good faith its obligations under a treaty to which it is a party, international law is not concerned with the way in which the treaty is implemented in the municipal legal order of that state. As long as a state does not invoke its municipal law "as justification for its failure to perform a treaty", ${ }^{2}$ the issue of how effect is given to the treaty in the municipal legal order belongs essentially to the province of municipal law, and is determined mainly by its perception of the desirability of seeking protection from the rules of international law or, reversely, of the desirability of relying on its municipal law. ${ }^{3}$ While the issue in question remains topical in many other countries, ${ }^{4}$ little, if

\footnotetext{
${ }^{1}$ For multilateral treaties to which China is a party, see the table covering the period between 1977 and 1986, in HUNGDAH CHIU, 'Chinese Attitude toward International Law in the Post-Mao Erá, 1978-1987', 21 International Lawyer (1987), at 1154-1158. Zhonggou Waijiao Gailan [Annual Review of China's Foreign Affairs] 1987-, ed. by the PRC Ministry of Foreign Affairs (World Knowledge Press, Beijing) provides a chronological table of both bilateral and multilateral treaties to which China is a party.

${ }^{2}$ Article 27 of the Vienna Convention on the Law of Treaties.

${ }^{3}$ Ko SwAN SIK, 'International Law in the Municipal Legal Order of Asian States: Virgin Land', in R.ST.J. MACDONALD (ed.), Essays in Honor of Wang Tieya (Dordrecht: Martinus Nijhoff Publishers, 1994) at 738.

${ }^{4} \mathrm{~A}$ recent example is the symposium organized by the United Kingdom National Committee of Comparative Law. See FrANCIS G. JACOBS and SHELlEY ROBERTS (eds.), The Effect of Treaties in Domestic Law (London: Sweet \& Maxwell, 1987). See also BEnEdeTto ConforTi, International Law and the Role of Domestic Legal Systems (Dordrecht: Martinus Nijhoff Publishers, 1993).
} 
any, has been written about the Chinese practice. ${ }^{5}$ The present study attempts to make an inquiry into the effect of treaties in the Chinese municipal legal order. Since the effect of treaties in the Chinese municipal legal order is determined by China's general attitude towards the relationship between international law and municipal law, the present inquiry may, hopefully, also shed some light on this broader question.

\section{THE SCOPE OF THE TERM TREATY AND THE TREATY-MAKING PROCEDURE}

\section{1. 'Treaties'}

In international law, the term 'treaty' is generally used to cover all binding agreements between subjects of international law that are governed by international law. ${ }^{6}$ Within the context of the Chinese municipal law, however, the term 'treaty' carries a special meaning. Article 67 of the Constitution of the People's Republic of China ('the Constitution') provides, inter alia, that the Standing Committee of the National People's Congress ('the NPC') "decide[s] on the ratification or abrogation of treaties and important agreements con-

\footnotetext{
${ }^{5}$ Hungdah ChIU, supra n.1, at 1147 . As Professor ChIU observes, the question of the effect of treaties in China's domestic system was usually ignored. Discussions on this subject are always conducted within the context of the general topic of the relationship between international law and municipal law. For the Chinese literature, see Zhou Gengsheng, Guoji Fa [International Law], (Beijing: Shangwu Chuban She, 1976) at 16-21; WANG TIEYA and WeI MiN (eds.), Guoji Fa [International Law], (Beijing: Falü Chuban She, 1981), at 42-47. The contemporary literature dealing with the PRC practice in this regard mainly focuses on the pre-1970 period. It includes Hungdah Chiu, The People's Republic of China and the Law of Treaties (1972); Jerome A. COHEN and HungdaH ChIU, People's China and International Law: A Documentary Study (1974); LuKE T. LEE, China and International Agreements (1969); JAMES CHIEH HsIUNG, Law and Policy in China's Foreign Relations: A Study of Attitudes and Practice (1972). The issue has been addressed more recently by two of China's most prominent scholars: LI HAOPEI, Tiaoyue Fa Gailun [The Law of Treaties] (Beijing: Falü Chuban She, 1987) at 379-404; WANG TIEYA, 'International Law in China: Historical and Contemporary Perspectives', 221 Collection of Courses (of the Hague Academy of International Law) (1990-II) at 326-333. The 1993 issue of the Chinese Yearbook of International Law opens a special forum to discuss the question. A number of scholars including the present author have participated in the discussion.

${ }^{6}$ A.D. MCNAIR, The Law of Treaties (1938) at 3. The 1969 Vienna Convention on the Law of Treaties also uses the term 'treaty' in its general sense. It is defined by Article 1 of the Convention as "an international agreement concluded between States in written form and governed by international law [. . .]”.
} 
cluded with foreign states". (emphasis added) ${ }^{7}$ Similar wording is employed in Article 89 of the Constitution, which prescribes that the State Council "conclude[s] treaties and agreements with foreign States". (emphasis added) Chinese doctrine generally accepts that the two distinct terms 'treaties' and 'agreements' are used purposely, each covering a different category of treaties.

This opinion finds support in the preparatory process which led to the enacting of the Procedure Law for the Conclusion of Treaties ('the PLCT'). ${ }^{8}$ Its draft-Article 2 reads:

"This statute applies to bilateral and multilateral treaties, conventions, agreements, protocols, and other documents which, by their nature, can be characterized as treaties". ${ }^{9}$

When this draft-article was submitted to the Standing Committee of the NPC for consideration, some legal experts advised this legislative body that the Constitution distinguishes between 'treaties' and 'agreements' and that the proposed statute should remain consistent with the Constitution in this regard. ${ }^{10}$ The text was therefore revised and Article 2 of the law finally reads as follows:

"This statute applies to bilateral and multilateral treaties and agreements which the People's Republic of China has concluded with foreign states and all other documents which, by their nature, can be characterized as treaties and agreements" (emphasis added). ${ }^{11}$

\footnotetext{
7 The present Constitution of the People's Republic of China is China's fourth constitution, and was adopted and came into force in 1982. For English text, see The Constitution of the People's Republic of China (Beijing: Foreign Languages Press, 1983), also in: The Laws of the People's Republic of China 1979-1982 (Foreign Languages Press, 1987). The PRC National People's Congress (NPC) is China's supreme national legislative organ, with a Standing Committee exercising its power when the Congress is not in session. The PRC State Council is the highest organ of state administration.

${ }^{8}$ The statute was adopted at the 17th session of the Standing Committee of the 7th National People's Congress on December 28, 1990 and came into effect on the same day. For a Chinese text, see Guowuyuan Fazhi Ju [Bureau of Legislative Affairs of the State Council], Zhonghua Remin Gonghe Guo Xin Fagui Huibian [Collection of the New Laws and Regulations of the People's Republic of China], Vol. 4 (Beijing: Xin Hua Chuban She, 1990) at 30-36.

${ }^{9}$ Renmin Ribao [People's Daily], 21 December, 1990.

${ }^{10}$ Ibid.

${ }^{11}$ English translation by the present author.
} 
Neither the Constitution nor the PLCT, however, specifies the category of treaties which each term is supposed to cover. In this regard, Chinese doctrine is of the opinion that the term 'treaties' is used in the Constitution in its narrow meaning, referring only to international agreements designated as 'treaty.' Agreements made under appellations other than 'treaty' are accordingly classified as 'agreements' ${ }^{12}$ The distinction would thus mainly serve to assign a sense of solemnity and importance to 'treaty,' as an instrument so designated is habitually used for more formal and important purposes. ${ }^{13} \mathrm{Be}$ that as it may, the particular appellation of an international instrument does not in itself affect the binding character of that instrument under international law. A 'treaty' is thus no more binding than an 'agreement' simply because the former is regarded more formal and important than the latter. On the other hand, however, the distinction bears significance in that a 'treaty' is accorded with a higher rank than an 'agreement' in the hierarchy of norms in the Chinese municipal legal order. ${ }^{14}$ In the present inquiry, unless otherwise indicated, the term 'treaty' will be used in its general meaning, covering all international agreements whatever their form or descriptive name used, to which China is a party.

Under Article 2 of the PLCT, any international instrument that by its very nature can be characterized as creating, altering, or terminating rights and obligations governed by international law falls into the scope of treaties, regardless of its appellation or modality. ${ }^{15}$ Article 16 of the PLCT requires

\footnotetext{
12 Wang Treya, Guoji Fa De Jige Wenti [On Certain Issues of International Law], in Deng Zhenglai (ed.), Wang Tieya Wen Xuan [Selected Essays of Wang Tieya] (Beijing: Zhongguo Zhengfa Daxue Chuban She, 1993) at 237, 494. In practice, however, the distinction is not strictly followed. Art. 142 of the General Principles of Civil Law adopted by the National People's Congress in 1986, for example, provides: "If any international treaty (emphasis added) concluded or acceded to by the People's Republic of China contains provisions different from those in the civil laws of the People's Republic of China, the provisions of the international treaty shall apply, unless the provisions are ones to which the People's Republic of China has announced reservations". Here, noticeably, the term 'treaty' must be understood in its broad sense which covers all international legal instruments to which China is a party regardless of their designation. A similar inconsistency can be found in the 1991 PRC Income Tax Law on Foreign Investment Enterprises and Foreign Enterprises, the 1991 PRC Civil Procedure Law, etc.

${ }^{13}$ See MCNAIR, op.cit. supra n. 6.

${ }^{14}$ This is true except for 'important agreements' defined by the PLCT. As will be discussed later, an 'important agreement' enjoys the same ranking as a 'treaty' in the hierarchy of norms of the Chinese municipal legal order.

${ }^{15}$ Whether such scope of coverage includes oral agreements is subject to subsequent clarification. The statute seems to rule out oral agreements by describing treaties as 'documents'. However, international transactions are not short of treaties which were concluded in oral form. A glaring example is the 'Ihlen Declaration', which was found binding on Norway by the Permanent Court
} 
that all treaties to which China is a party should be compiled by the Ministry of Foreign Affairs into the PRC Treaty Series. To the extent that the PRC Treaty Series serves as the official collection of treaties in China, any instrument included in the Series can therefore be regarded as a treaty from the perspective of China. ${ }^{16}$

\subsection{Treaty-Making Power and Procedure}

China adheres to a unitary state system, in which the power to conclude treaties with foreign states rests exclusively with the central organs of the state, namely the NPC (as occasion requires) and its Standing Committee, the State Council, and the President. The treaty-making power is part of their respective competences in the field of legislation, administration, and representation as set out by the Constitution. ${ }^{17}$ Accordingly, local governments in China

of International Justice in the Legal Status of Eastern Greenland case (1933 PCIJ, Ser. A/B, No. 53, at 22). LI HAOPEI, supra $\mathrm{n}$. 5, at 14-18.

${ }^{16}$ A glance at the PRC Treaty Series reveals that China's treaties include conventions, agreements, protocols, exchanges of notes, exchanges of correspondence, agreed minutes, minutes of talks, memorandum of understanding, measures for implementation, joint declarations, joint communiques, joint announcements, regulations, and even contracts and general conditions. In addition, charters, covenants, acts, arrangements, parallel unilateral statements and modus vivendi are also used as forms of treaties. As of 1990, 19 volumes of the PRC Treaty Series have been published, which cover a period from 1949 to 1983 and include a total of 2,337 international treaties to which China is a party. Of these 2,337 treaties, 2,295 are bilateral, which have involved 127 States and 42 multilateral treaties. WANG TIEYA, supra $\mathrm{n}$. 5, at 317-318. For more recent information, see supra $\mathrm{n} .1$.

${ }^{17}$ The NPC is the highest organ of state power in China. Its permanent body is the NPC Standing Committee. Both the NPC and its Standing Committee exercise the legislative power of the state. The NPC is empowered to amend the Constitution and to enact basic statutes concerning criminal, civil, administrative and other matters. Its Standing Committee has the power to enact and amend statutes except those falling under the competence of the NPC, or to enact, when the NPC is not in session, partial supplements and amendments to statutes enacted by the NPC, provided that they do not contravene the basic principles of these statutes.

Although the Constitution does not expressly authorize the NPC to decide on the ratification of treaties, such power can be inferred from Art. 62 of the Constitution, under which the NPC is empowered to "exercise such other functions and powers as the highest organ of state power should exercise". A recent example is the NPC's decision on the ratification of the 1984 SinoBritish Joint Declaration on the Question of Hong Kong.

The State Council is the executive body of the highest organ of state power; it is the highest organ of state administration. It has the power to adopt administrative measures, enact administrative rules and regulations and issue decisions and orders in accordance with the constitution and statutes.

The PRC President is responsible for having statutes and statutelike decisions of the NPC and its Standing Committee promulgated. 
generally do not possess treaty-making capacity. ${ }^{18}$ As provided for by the Constitution and the PLCT, the treaty-making power in China is exercised by the above-mentioned state organs through acts including ratification, approval, and signature. ${ }^{19}$

In state practice, a treaty on matters of importance often requires ratification by the states concerned as the formal means of expressing their consent to be bound on the international plane. ${ }^{20}$ Ratification usually involves two distinct but related acts.

First, within the domestic context ratification signifies the procedure whereby the state puts itself in a position, as provided by its constitution, to decide whether it will accept the treaty. ${ }^{21}$ In China, as required by Articles 62 and 67 of the Constitution and Article 7 of the PLCT, 'treaties and important agreements', after being signed, must be submitted by the State Council to the Standing Committee of the NPC or the NPC itself (as occasion requires ${ }^{22}$ for its decision on ratification. According to Article 7 of the PLCT, 'treaties and important agreements' include:

1. Political treaties, such as treaties of amity and cooperation, treaties of peace, etc.;

2. Treaties and agreements concerning territories and delimitation of boundaries;

3. Treaties and agreements concerning extradition and judicial assistance;

4. Treaties and agreements of which the provisions contravene the laws of the People' s Republic of China;

Under Arts. 62, 67, 89, and 81 of the Constitution, the treaty-making power fits into the various scopes of the legislative competence of these central state authorities.

${ }^{18}$ On 1 July, 1997, China will resume its sovereignty over Hong Kong, and from that date Hong Kong will become a special administrative region of China (HKSAR). Under the Basic Law of the Hong Kong Special Administrative Region adopted by the NPC, the HKSAR will be accorded the power to conclude certain types of treaties with foreign states and international organizations. However, this power is by no means an independent one under international law. It is rather the power delegated to the HKSAR by the NPC and guaranteed by the Sino-British Joint Declaration on the Question of Hong Kong. Moreover, the power will be exercised only within limited areas. For the Sino-British Joint Declaration, see 23 ILM (1984) 1366-1387.

${ }^{19}$ Under Article 4 of the PLCT, the procedures for the conclusion of treaties depending on whether the treaty is concluded in the name of the PRC, the PRC government (the State Council), or a PRC government department.

${ }^{20}$ Although the signature as such is not without legal effect under general international law. See Art. 18 of the 1969 Vienna Convention on the Law of Treaties.

${ }^{21}$ Professor BROWNLIE describes this as ratification in the constitutional sense. IAN BROWNLIE, Principles of Public International Law, 4th ed., (Oxford: Clarendon Press, 1990) at 607.

${ }^{22}$ The 1984 Sino-British Joint Declaration on the Question of Hong Kong was ratified by the NPC. 
5. Treaties and agreements which must be ratified under the agreement of the contracting parties;

6. Other treaties and agreements which require ratification. ${ }^{23}$

It is submitted that the decision taken by the Standing Committee of the NPC on the ratification of 'treaties and important agreements' does not in itself constitute ratification on the international plane stricto sensu but, instead, the mere approval of their eventual ratification. ${ }^{24}$

Such ratification in the constitutional sense must be distinguished from the ratification as "the international act so named whereby a state establishes on the international plane its consent to be bound by a treaty." 25 It is the ratification in this latter sense which binds the state to the treaty in question in terms of international law. Ratification as such is an act usually executed by the head of state. In this regard, Art. 81 of the Constitution prescribes that the President, pursuant to the decision of the Standing Committee of the NPC, ratifies 'treaties and important agreements.' The article thus provides the President with the constitutional authority to ratify treaties on behalf of China, and upon such ratification a treaty will become binding on China as a matter of international law. ${ }^{26}$ Usually, ratification executed by the President is promulgated in the official Chinese newspaper and communicated to the other party(ies) through exchange of the Instrument of Ratification, which is, on the Chinese side, signed by the President and co-signed by the Foreign Minister. ${ }^{27}$

The need of ratification in order to bring 'treaties and important agreements' into effect rests on the assumption, so far as China is concerned, that since the vital national interests of China are involved in these treaties, the requirement of ratification gives the Chinese government an opportunity to reexamine and review the instrument signed by its delegates before committing itself to the obligations specified therein. The period between signature and ratification enables China to further reflect on the merits involved in the

\footnotetext{
${ }^{23}$ Translation by the author.

${ }^{24}$ BROWNLIE, op.cit. supra $\mathrm{n} .21$.

${ }^{25}$ Art. 2(1)(b) of the Vienna Convention of the Law of Treaties. See also WANG TIEYA, supra n. 10 , at 236,494 . The decision made by the municipal legislature on the ratification of a treaty is not required by international law. Some countries, such as the United Kingdom and Canada, do not even require parliamentary ratification for most treaties. Thus, under international law, a treaty, even if 'ratified' by the municipal legislature, has no legal validity pending the ratification by the head of the state. LI HAOPEI, supra $\mathrm{n} .5$, at 74.

${ }^{26}$ WANG, supra $\mathrm{n}$. 5, at 328 .

${ }^{27}$ In the case of multilateral treaties, the Instrument of Ratification will be delivered to the depository state or international organization.
} 
proposed instrument so that it can make its final decision with the highest measure of circumspection. The more careful the preparation of the treaty and the more deliberate the decision to accept it, the more likely is the treaty to be founded upon the interests of the parties and to be observed by them. ${ }^{28}$

In fact 'treaties and important agreements' amount only to a small part of the treaties concluded by China. The majority deal with matters concerning everyday business of various government departments. These treaties are usually of a technical nature and, consequently, do not necessitate a decision of the Standing Committee of the NPC on their ratification. In order to facilitate the conclusion of this type of treaties, the required approval is devised as a simple procedure. Article 89 of the Constitution prescribes that the State Council is empowered to enter into 'treaties and agreements' with foreign states. According to Article 8 of the PLCT, this power has been designed partly for giving approval to treaties falling short of 'treaties and important agreements' 29 , either pursuant to a decision of the State Council or as required by the agreement itself. The approval given by the State Council is communicated to the other contracting party(ies) through the exchange of the Letters of Approval. This letter is signed on the Chinese side by the Premier of the State Council or the Foreign Minister. ${ }^{30}$

China may participate in a multilateral treaty which it has not signed as an original party, through accession. Where the treaty belongs to the category of 'treaties and important agreements', a procedure similar to ratification is required. By the same token, if the treaty in question is characterized as an 'agreement', the approval of the State Council on the accession constitutes the final confirmation of China's consent to be bound. ${ }^{31}$ In case of a multilateral treaty which contains a clause of acceptance, the State Council decides on its acceptance. ${ }^{32}$

Article 9 of the PLCT refers to another category of treaties, which come into effect by the mere signature per se by duly authorized delegates. Such a 'fast-track' treaty-making procedure is necessary due to the demand for an

\footnotetext{
${ }^{28}$ LI HAOPEI, supra $\mathrm{n}$. 5, at 76-77.

${ }^{29}$ According to Art. 3 PLCT, the treaty-making power of the State Council manifests itself in conducting negotiations toward a treaty, signing a treaty, and administering all other matters related to its conclusion.

30 The Ministry of Foreign Affairs is responsible for the exchange of letters of approval or sending the letter of approval to the depository state or international organization as the case may be. Unlike the exchange of a Letter of Ratification, approval of a treaty can also be notified to the other party by a diplomatic note or through mutual notifications.

${ }^{31}$ Article 11 of the PLCT.

${ }^{32}$ Article 12 of the PLCT.
} 
efficient and effective handling in view of the rapid increase of such treaties which are made to deal with matters of detail concerning, e.g., international trade, payments, and exchange rates; rail, air, and maritime transportation; technology assistance and cooperation; cooperation on medical and health matters; arrangements concerning telecommunication, postal, and broadcasting services; agricultural cooperation; and exchange of students and technical trainees. ${ }^{33}$ Apparently neither ratification nor approval can satisfy this purpose. Under Article 9 PLCT, this type of treaties only need to be registered with the Ministry of Foreign Affairs if concluded in the name of a government department and, else, to be filed with the State Council.

Unlike Western-modeled democracies, the treaty-making procedure in China is characterized by so-called democratic centralism. This means that the NPC or its Standing Committee decides on ratification or, in the case of the State Council, on approval of a treaty on the basis of broad consultation with, and solicitation of opinions from, all sides concerned. Only after such consultation will the central authorities make their decision. This procedure implies that, between the negotiation of the treaty and its submission for ratification or approval, consensus must be reached among the government departments and institutions concerned, in order to ensure that the proposed instrument is compatible with the requirements of the Chinese municipal law. Hence, the embarrassing situation in which the central authorities refuse to ratify or approve a treaty, has never occurred in China. So far as the presidential powers are concerned, these must be exercised only pursuant to the decisions of the NPC or its Standing Committee. Therefore, once the NPC or its Standing Committee decides to ratify a treaty, the President is obliged under the Constitution to execute that decision. To act otherwise would certainly violate the Constitution, which can not conceivably happen in the present political system of China.

\section{EFFECT OF TREATIES IN THE CHINESE MUNICIPAL LEGAL ORDER}

The implementation of a treaty in the Chinese municipal legal system presupposes that the said treaty is internationally valid in the view of the Chinese

${ }^{33}$ LI HAOPEI, supra n. 5, at 86. 
municipal law. ${ }^{34}$ Next, the said treaty must be accepted into the Chinese municipal legal order, that is to say, it must be accorded the same legal validity as Chinese municipal law. In the preceding inquiry we have discussed the question of how a treaty attains its validity under international law as prescribed by the Constitution and the PLCT. The following discussion will be focused on the second question, namely on what conditions a treaty is accorded municipal validity in order to qualify for application in the Chinese municipal legal order.

\subsection{Municipal Validity of Treaties}

In state practice, treaties which have come into force on the international plane, acquire municipal validity mainly through the following two approaches. ${ }^{35}$ The first approach may be characterized as 'transformation', under which an internationally valid treaty has, of itself, no municipal validity, and, in order to bring about that effect, must be transformed into municipal law through legislative acts. The second approach may be described as 'adoption', whereby a treaty, after acquiring international validity as prescribed by the municipal law, will be made part of the municipal legal order without the necessity of 'transformation'. Whatever approach a state takes for granting municipal validity to a treaty, it is usually the constitutional law of the state concerned which governs the matter in question.

In China the constitution is conspicuously silent on this question. Nor have there been other legislative acts to address this matter. Nevertheless, Chinese scholars generally maintain that the Chinese system takes 'adoption' as the method for bringing about municipal validity of treaties which have come into effect upon China. A standard Chinese textbook on basic legal theory typically reflects such opinion. It states:

"International treaties are various kinds of agreements which two or more states form to regulate their rights and obligations concerning political,

\footnotetext{
${ }^{34}$ Non-fulfillment of the constitutional requirements as to the international validity of a treaty, it should be noted, does not necessarily lead to the international invalidity of the treaty. Art. 46 (1) of the Vienna Convention states: "A State may not invoke the fact that its consent to be bound by a treaty has been expressed in violation of a provision of its internal law regarding competence to conclude treaties as invalidating its consent unless that violation was manifest and concerned a rule of its internal law of fundamental importance".

${ }^{35}$ JACOBS and ROBERTS, supra n. 4, at xxiv-xxvi.
} 
economic, legal, scientific and technological, cultural, and military affairs. International treaties which China concludes or accedes to acquire their legal effect upon ratification by the highest organs of state power of China, and thus become a form of law binding upon China's state organs, social organizations, enterprises and institutions, and individual citizens as well." ${ }^{36}$

Accordingly, it is the prevailing Chinese view that a treaty, after entering into force in accordance with the Constitution and the PLCT, will become part of the Chinese municipal legal order without the need of transforming it into a municipal statute. ${ }^{37}$ This is confirmed by many statutes enacted by the Chinese legislature. A typical example is Article 238 of the Civil Procedure Law, which provides:

"If an international treaty that the People's Republic of China has concluded or acceded to contains provisions that are inconsistent with this law, the provisions of the international treaty shall prevail, except for those provisions to which the People's Republic of China has declared its reservations". ${ }^{38}$

Accordingly, no transformation of a treaty is required as a condition for its applicability in legal proceedings in China. Although Article 238 itself can not be said to grant municipal validity to a treaty, the authorization for direct application of treaty law presupposes such validity. Given the silence of the Constitution, Article 238 of the Civil Procedure Law and similar provisions of other statutes must have been based on a generally established assumption or state policy that a treaty, after entering into force for China, automatically becomes part of the Chinese municipal legal order.

\footnotetext{
36 Wang Tianmu (ed.), Faxue Jichu Lilun Jiaocheng [A Textbook on the Basic Theories of Law] (Beijing: Falü Chuban She, 1986) at 221. Translation by the present author.

${ }^{37}$ According to WANG TIEYA, when the present Constitution was being drafted in the early 1980s, the question of the effect of treaties in China's municipal law seemed to have been deliberated. Considering that the then Chinese practice had not yet sufficiently matured to be embodied in an express provision, the authorities decided that the Constitution should be silent on this question. WANG, supra $\mathrm{n} .12$, at 230 . This may partly explain the silence of the Constitution on the matter. But it was taken for granted that all treaties to which China is a party have the effect of law in China's municipal legal system. For instance, PERRY Keller noticed in his interview with officials of the PRC Ministry of Foreign Affairs that it is China's policy that treaties have legal effect in China's municipal law upon their ratification. PERRY KELLER, 'Freedom of the Press in Hong Kong', 27 Texas International Law Journal (1992) at 392.

${ }^{38}$ English translation of Article 238 cited from 5 China Law and Practice, 17 June, 1991, at 56. The PRC Civil Procedure Law entered into force on 9 April 1991, and replaced the 1982 Civil Procedure Law (for Trial Implementation). For the official text of the present law, see Zhonghua Renmin Gongheguo Quanguo Renmin Daibiao Dahui Changwu Weiyuanhui Gongbao [Gazette of the Standing Committee of the PRC National People's Congress] 1991 No. 3, at 41.
} 
China's diplomatic practice in recent years also attests to the correctness of this observation. On 14 November 1991, the Chinese delegate to the Third Committee of the General Assembly of the United Nations presented an official statement about China's attitude towards the prohibition of torture and other inhuman and cruel treatment of prisoners. The Chinese delegate put on record that China, as a party to the UN Convention against Torture and Other Cruel, Inhuman or Degrading Treatment or Punishment, would fulfill in good faith its legal obligations under the Convention, and, within the scope of its obligations, exercise jurisdiction over any offence specified by the Convention, whether or not committed in China. In regard to the question concerning the validity of the Convention in the Chinese municipal legal order, the statement made it clear that, according to Chinese law, as soon as a treaty is ratified or acceded to by the Chinese government, and comes into force for China, the Chinese government will fulfill its obligations arising therefrom without the necessity of transforming that treaty into municipal law. In other words, the Convention had acquired validity in the Chinese municipal legal order upon its ratification by China. ${ }^{39}$

This official statement is most significant, it is submitted, not only because it reaffirmed the determination of the Chinese government to fulfill its international legal obligations under the Convention, but also because, in doing so, it made known to the international community China's position as to how treaties acquire municipal validity in China. As such the statement may be seen as the most authentic and reliable evidence of the Chinese position.

As will be discussed later, under the present Chinese system a treaty rule enjoys an exclusive trumping effect over conflicting municipal law rules. The adherence to the adoption doctrine may introduce an element of danger of altering conflicting municipal law rules by way of a treaty without the consent of the Chinese legislative authorities. This concern is particularly warranted as the majority of treaties are concluded by means of the simplified treaty-making procedure, which do not involve the participation of the Standing Committee of the NPC. In order to prevent the municipal law from being unduly interfered by international treaties, many states where the adoption method is employed in conferring municipal validity to treaty law have devised a certain measure of legislative control over the treaty-making power. So has China. Article 7(5) of the PLCT provides that a treaty which contravenes the laws of

\footnotetext{
${ }^{39}$ UN doc. A/C.3/46/SR.41 para.12. Thus, any act which can be characterized as torture, and cruel, inhuman, or degrading treatment or punishment against prisoners as specified by this convention has been and will be strictly prohibited. Renmin Ribao [People's Daily, overseas edition], 16 November 1991, at 4.
} 
China shall be submitted to the Standing Committee of the NPC for its decision on ratification. Therefore, it is on the basis of a decision of the Standing Committee of the NPC that the provisions of a treaty can prevail over conflicting municipal rules.

\subsection{Direct Application of Treaties}

For the purpose of this inquiry, the term 'direct application' of treaties means that rules of internationally valid treaties are directly applied within the scope of the competence of the Chinese courts and other appropriate authorities, or to use the Chinese legal parlance, "the specialized law-applying authorities", in the same manner as municipal law rules. In this sense, a directly applicable treaty rule is one which can be invoked in Chinese legal proceedings as the source of rights and obligations asserted by parties concerned. ${ }^{40}$

The question of direct application of treaties in the Chinese municipal legal order should be distinguished from that of municipal validity which internationally valid treaties acquire. While the direct application of a treaty presupposes the municipal validity of that treaty, it does not follow that all treaties which have acquired municipal validity are directly applicable. This is because, first, treaties vary in their subject matters, and it is hardly conceivable that all treaties to which China is a party address subject matters which fall within the scope of the competence of the appropriate Chinese authorities as set out by the Constitution; second, not all treaties have the mandatory quality required for their direct application in the Chinese municipal order. Accordingly, where internationally valid treaties forms part of the municipal legal system without transformation, it is necessary to distinguish between directly applicable and indirectly applicable treaties. ${ }^{41}$

\footnotetext{
${ }^{40}$ JACOBS and ROBERTS, supra n. 4, at xxvii. Also JACKSON is of the opinion that the term 'direct application' expresses the notion that an international treaty has a direct statute-like role in the domestic legal system. Thus, the term should not limited only to the situations where private parties can file a law suit on the basis of the treaty provisions, but will also cover the situations where government can use the treaty provisions as part of domestic law. J.H. JACKSON, 'Status of treaties in domestic legal systems', 86 AJIL (1992), at 310 and 321. Often 'direct application' is mixed up with the term 'self-executing', and in many cases they address similar issues. However, this author is of the opinion that 'direct application' is more appropriate in addressing the issue of applying treaties in the municipal order.
}

${ }^{41}$ LI HAOPEI, supra $\mathrm{n}$. 5, at 392. 
The concept of the direct application of treaties was first developed in the United States in Foster and Elam v. Neilson in 1829.42 The California Supreme Court's decision in Fujii v. California $(1952)^{43}$ that the provisions of the Charter of the United Nations on human rights are not 'self-executing' in the legal system of the United States has further exerted impact on the development of this concept elsewhere. Today states have generally accepted the distinction between the two categories of treaties in the municipal legal system. ${ }^{44}$ There is, however, no uniform criterion as to where the line should be drawn between directly applicable treaties and non-directly applicable ones. Opinions among scholars on this matter vary. An inconclusive survey suggests that the following four types of treaties may be viewed as non-directly applicable in the practice of various states: political treaties which may not give 'cause of action' within the municipal legal sphere; treaties which expressly require further legislative acts of the contracting parties for their implementation; treaties which address matters lying within the exclusive lawmaking power of the legislative authorities of the state; treaties which merely impose obligations in principled terms on the contracting parties without mandatory quality for the purpose of application in concrete cases. ${ }^{45}$ These four criteria may serve as useful measures in evaluating the practice of states.

The present discussion attempts to focus on some distinctive features which Chinese practice has so far revealed in regard to the direct application of international treaties in the Chinese municipal legal system. Again, the Constitution is silent on the matter, there are no legislative acts addressing the issue, nor are there instructive Chinese court decisions on the subject. ${ }^{46}$ On

\footnotetext{
4227 US(2 Pet)253, 7 L.Ed. 415. The American jargon for directly applicable treaties is 'selfexecuting treaties'. See Restatement of the Foreign Relations Law of the United States (Third) (American Law Institute, 1987) § 111; LouIS HENKIN et al., International Law Cases and Materials, 3rd Ed. (St. Paul: West Publishing Co., 1993) at 212-221.

${ }^{43} 38 \mathrm{Cal} .2 \mathrm{~d}$ at 724,242 P.2d at 621-22.

44 While American practice has exerted great impact on other countries, it has also caused a great deal of confusion. On the one hand, the American Constitution recognizes that treaties are part of the "supreme law of the Land." On the other hand, however, the American system puts on constitutional restraints under which a treaty, even if it has the quality that the municipal law carries for the purpose of application by courts, can not take effect as domestic law without implementation by Congress if the treaty deals with matters which are within the exclusive lawmaking power of Congress under the American Constitution.

${ }^{45}$ Max Planck Institute for Comparative Public Law and International Law, Encyclopedia of Public International Law (New York: North-Holland, 1984) installment. 7, at 414-416.

${ }^{46}$ While cases involving direct application of treaties by Chinese courts are increasing in recent years, they hardly throw light on the matters in question. This is mainly because the Chinese courts usually do not give legal reasonings for their decisions.
} 
the other hand, there are a number of statutes which contain provisions permitting the direct application of treaties in the Chinese municipal system. A typical example is Article 238 of the Civil Procedure Law, which has been discussed earlier in a different context. Other statutes containing similar provisions are: ${ }^{47}$

- Law on Economic Contracts Involving Foreign Interests (1985), Article 6;

- General Principles of Civil Law (1986), Article 142;

- Regulations for Diplomatic Privileges and Immunities (1986), Article 27;

- Law on National Border Health and Quarantine (1986), Article 24;

- Law on Postal Service (1986), Article 42;

- Law on the Control of Water Pollution (1988), Article 51;

- Law on the Protection of Wild Animals (1988), Article 40;

- Administrative Procedure Law (1989), Article 72;

- Law on Environmental Protection (1989), Article 46;

- Regulations for Consular Privileges and Immunities (1990), Article 27;

- Income Tax Law for Foreign Investment Enterprises and Foreign Enterprises (1991), Article 28;

- Law on the Quarantine for the Entry and Exit of Animals and Plants (1991), Article 47;

- Law on the Control of Taxation (1992), Article 59;

- Maritime Law (1992), Article 268;

- Regulations for the Implementation of International Copyright Treaties (1992), Article 19.

According to these laws, whenever their provisions are in conflict with those of a treaty to which China is a party, the Chinese authorities shall apply the provisions of the said treaty. ${ }^{48}$

Among the statutory provisions, Article 142 of the PRC General Principles of Civil Law is worth special attention. It reads:

"If any international treaty concluded or acceded to by the People's Republic of China contains provisions differing from those in the civil laws of the People's Republic of China, the provisions of the international treaty shall

\footnotetext{
${ }^{47}$ All these statutes are contained in the annually published Zhonghua Remin Gongheguo Falü Huibian [Collection of the Laws of People's Republic of China] (Beijing, Falü Chuban She). ${ }^{48}$ The earliest statutes containing such provisions are the 1980 Sino-Foreign Equity Joint Venture Income Tax Law and the 1981 Foreign Enterprise Income Tax Law, which have been replaced by the 1991 Income Tax Law for Foreign Investment Enterprises and Foreign Enterprises.
} 
apply, unless the provisions are ones on which the People's Republic of China has announced reservations. ${ }^{49}$

As appears from its title, this statute was enacted to establish the basic framework of the Chinese civil law system. Consequently, the principles and rules prescribed in it are formulated in quite general terms and are to be followed by subsequent, more specific legislation. ${ }^{50}$ Accordingly, to the extent that Article 142 provides that the provisions of a treaty shall prevail over conflicting rules of the 'civil laws', this article is to be interpreted as applying not only to the provisions of this particular statute but also to all subsequently enacted laws which, by their nature, fall into the 'civil laws' branch of the Chinese municipal legal system. ${ }^{51}$ The PRC Law on Adoption, for instance, does not contain a provision on the direct application of treaty law to adoption of children in China. But as the Law constitutes part of the 'civil laws' of the Chinese municipal legal system, a treaty can be directly applied on the basis of Article 142 of the General Principles of Civil Law, if it is established that the Adaption Law contains provisions inconsistent with those of the treaty in question. It is thus with this omnipotent article that treaties to which China is a party can be directly applied throughout all property and personal relations between subjects of equal status" as provided by the PRC General Principles of Civil Law. ${ }^{52}$

\footnotetext{
${ }^{49}$ English translation is cited from The Laws of the People's Republic of China 1983-1986, compiled by the Legislative Affairs Commission of the Standing Committee of the National People's Congress of the People's Republic of China (Beijing: Foreign Languages Press, 1987) at 247.

${ }^{\text {so }}$ In China's law-making process for civil law matters, instead of developing a comprehensive civil code right away, the Chinese legislature first drew up a body of general principles and applied these general principles as guidance and basis for the subsequent development of more detailed branches of civil law.

${ }^{51}$ The official translation of the statute uses the term "civil laws" for minshi falü [law for civil affairs]. The plural form of the term strongly suggests the comprehensive coverage of this statute. ${ }^{52}$ Art. 2 of the PRC General Principles of Civil Law. A hypothetical case could be the adoption of children. Assuming that China concluded a treaty allowing private citizens of each contracting party to adopt children living in the territory of the other contracting party, and assuming that the provisions of this hypothetical treaty contain a regulation on the subject matter differing from the Chinese municipal law. Even if the municipal law on adoption would not specifically allow international treaties to prevail over the former's conflicting rules, a national of the other contracting party who would like to adopt a child in China would still be able to avail himself of the treaty regulation by arguing before the Chinese court that the treaty rules have priority on the basis of Article 142 of the General Principles.
} 
According to the above statutory provisions on direct application of treaty law, this direct application is conditioned on a conflict or discrepancy between treaty provisions and those of municipal law. Thus, the underlying idea is the solution of that conflict. In other words, even if a treaty possesses the mandatory quality of direct application, the Chinese authorities do not have to apply it unless they find the municipal law regulating the same transaction inconsistent with the provisions of the treaty in question. Under such a conflict-solution-oriented system, the mechanism of the direct application of treaties in the Chinese municipal legal system leaves a fair amount of latitude to the municipal authorities for interpretation whether there is in fact a discrepancy between the treaty and the related municipal law. Only if they find such discrepancy as a result of their interpretation, will the question about the direct application of the said treaty arise. To this extent, it is submitted that, whether or not a treaty is directly applicable will depend on the interpretation of the treaty and the related municipal law. ${ }^{53}$

On the other hand, the evidence of discrepancy between the treaty provision and the municipal rule alone does not suffice to establish a basis for the direct application of the treaty. Besides, the treaty provision must have the mandatory quality for direct application, prescribing rights and obligations which can be directly applied within the scope of the competence of the municipal law-applying authorities. This raises the question of criteria for the determination of the direct applicability of a treaty. It is an essential question faced by every state in which treaties are given municipal law effect through adoption. Answers to this question are usually found in the practice of the lawapplying authorities in general and in court decisions in particular.

\footnotetext{
${ }^{53}$ For instance, Art. 21 para. (a) of the UN Convention on the Rights of the Child, to which China acceded in 1992, provides that a state shall "ensure that the adoption of a child is authorized only by competent authorities" of that state. Under the PRC Law for Adoption, however, the authorization by the competent authorities does not constitute the sine qua non for the establishment of the relationship of adoption in China. Under the present Chinese system of residence registration, the relationship of adoption can not be effectively established pending the registration of the adopted child into the adoptive family for residence by the competent authorities. The registration as such is regarded as the exercise of the authorization as required by the Convention. The prima facie conflict between the Law on Adoption and the relevant provisions of the Convention is thus solved through the interpretation of the former, and the Chinese authorities do not have to directly apply the provisions the Convention. See WANG LIYU, "Guoji Tiaoyue Zai Zhongguo Guonei Fa De Shiyong" [Application of international treaties in China's municipal law], Zhongguo Guoji Fa Niankan [Chinese Yearbook of International Law] 1993.
} 
The present Chinese practice in this respect is, however, not quite revealing. In giving decisions involving the direct application of treaties, the Chinese courts rarely provide a legally reasoned explanation of why the treaty is applied as the governing law. No other manifestations of state practice either are available to throw light on the question. Be that as it may, scholars generally acknowledge the importance and necessity to identify such criteria. ${ }^{54}$ In this author's view, to the extent that the direct application of a treaty in the Chinese municipal legal system is conditioned upon a conflict between the treaty rule and a relevant rule of municipal law, the logical test of the direct applicability of the treaty rule should be its mandatory quality as measured against that of the conflicting municipal law. In other words, direct applicable treaty rules within the Chinese municipal legal order should be those which are as precise and specific as those of the conflicting municipal law.

Under the present Chinese municipal legal system, certain aspects of a subject matter may be specifically placed directly under the authority of treaty law. Such referral to treaty law is contained in statutory law dealing with subject matters of a civil, administrative, or commercial nature. In case of a transaction relating to a matter which has been so yielded to the authority of a treaty, the latter is to be directly applied. Although the direct application of the treaty under these circumstances is not conditioned on a conflict between a treaty and relevant municipal law, the treaty still needs to have the mandatory quality for direct application. It is submitted that the criterion to be applied should be the same as in the cases mentioned earlier, that is the measuring of the mandatory quality against that of the rules of the municipal law that has referred the subject matter to treaty law.

A typical statutory rule authorizing the direct application of a treaty as the proper law governing a transaction is Article 9 of the PRC Trademark Law. This article provides:

"Where a foreigner or foreign enterprise applies for trademark registration in China, the matter shall be handled in accordance with any agreement between the country to which the applicant belongs and the People's Republic of China or any international treaty to which both countries are parties, [ . . .]"55

\footnotetext{
${ }^{54}$ LI HAOPEI, supra n. 5, at 392.

${ }^{55}$ English translation is cited from The Laws of the People's Republic of China 1979-1982, compiled by the Legislative Affairs Commission of the Standing Committee of the National People's Congress of the People's Republic of China (Beijing: Foreign Languages Press, 1987) at 306.
} 
Thus, when such 'matter' as defined by this article arises, parties concerned can directly invoke relevant treaties to which China is a party as the source of the rules governing their trademark registration.

In 1985, China acceded to the Paris Convention for the Protection of Industrial Property. Under the Convention, persons (natural and legal) in each contracting party are entitled to the application of the relevant provisions of the Convention to the registration of their trademarks in other contracting parties. The State Council on 15 March 1985 issued the Interim Rules for Applying for Prior Registration of Trademarks in China. ${ }^{56}$ The Rules prescribe that applications made by nationals of the member states of the Convention for the prior registration of trademarks in China should be dealt with according to Article 9 of the Trademark Law and Article 4 of the Paris Convention. ${ }^{57}$

Other areas where the same approach is followed for the direct application of treaties include inheritance involving foreign interests, immigration (the administration of foreign nationals entering and leaving China), international shipping, etc. For example, Article 35 of the Law on Succession prescribes that the inheritance of property involving foreign interests is governed by the law of the country of residence of the deceased in case of movable property and by the law of the country where the property is located in case of immovable assets. But if there is a treaty governing the matter, to which China is a party, the treaty is to be applied in any case. ${ }^{58}$ According to the Law on the Administration of Foreign Nationals Entering and Leaving China, matters concerning the entry into and exit from China by the nationals of neighboring countries who live in the border areas are dealt with in conformity with the agreements concluded between China and the foreign countries concerned. Similarly, Article 12 of the Rules for the Control of International Maritime Container Transport issued by the State Council requires that the use of containers for international maritime transport conforms with the relevant international treaties governing the subject matter.

Today, judicial assistance is becoming another prominent area within the Chinese municipal legal order for the direct application of treaties. In this regard, Articles 262, 268, and 269 of the Civil Procedure Law provide, respectively:

\footnotetext{
${ }^{56}$ For the text of the Interim Rules, see Thomas C. W. ChIU, P.R.C. Laws for China Traders and Investors (2nd ed) at 644.

${ }^{57}$ There also exist a number of bilateral agreements between China and other countries concerning trademark registration. Ibid, at 663-91.

${ }^{58}$ The direct application of a treaty is not occasioned by the possible or consequent discrepancy between the municipal provisions and the treaty. Even if there is no such discrepancy, the treaty is still the governing law.
} 
[Art.262] "Pursuant to international treaties concluded or acceded to by the People's Republic of China or in accordance with the principle of reciprocity, People's Courts and foreign courts may request mutual assistance in the service of legal documents, investigation, taking of evidence, and other acts in connection with litigation, on other's behalf."

[Art.268] "Having received an application or a request for recognition and execution of a legally effective judgment or ruling of a foreign court, a People's Court shall review such judgment or ruling pursuant to international treaties concluded or acceded to by the People's Republic of China or in accordance with the principle of reciprocity [. . .]."

[Art.269] "If an award made by a foreign arbitration organ must be recognized and executed by a People's Court of the People's Republic of China, the party concerned shall directly apply to the Intermediate People's Court of the place where the party subject to execution is domiciled or where his property is located. The People's Court shall handle the matter pursuant to international treaties concluded or acceded to by the People's Republic of China or in accordance with the principle of reciprocity." 59

According to these articles, parties concerned can refer to the relevant treaty provisions as a direct basis for their requests for and provision of judicial assistance. ${ }^{60}$

China has acceded to the 1958 New York Convention on the Recognition and Enforcement of Foreign Arbitral Awards and the 1965 Hague Convention on the Service Abroad of Judicial and Extrajudicial Documents in Civil and Commercial Matters, ${ }^{61}$ and has also concluded a number of bilateral treaties

\footnotetext{
${ }^{59}$ English translation is cited from 5 China Law and Practice, 17 June 1991, at 59-60.

${ }^{60}$ Some of these treaties which are regarded as not conferring rights on individual parties may nevertheless be applied by the courts, and individual parties may claim the application of the treaty provisions in specific cases.

${ }^{61}$ China acceded on 2 December 1986 to the former Convention which came into effect for China on 22 April 1987; China acceded to the latter Convention on 22 March 1991, which came into force for China on 1 January 1992.
} 
on judicial assistance. ${ }^{62}$ Some of these treaties confer a right upon private subjects to request judicial assistance in the courts of the contracting parties. Under Article 4 of the New York Convention, for instance, a person (natural and legal) from a state party to the Convention is entitled to request a court of another state party to recognize and enforce an award rendered by an arbitral tribunal of the former state. Similarly, under the 1987 Sino-French Agreement on Judicial Assistance in Civil and Commercial Matters, persons (natural and legal) of the contracting parties are entitled to proceed directly to seek the recognition and enforcement of a final judgment or arbitration award rendered by a court or arbitral tribunal of one party in the court of the other party.

In order to ensure the direct application of the above treaties by the Chinese courts, the Supreme People's Court has issued a number of judicial notices. The Notice on the Implementation of the Convention on the Recognition and Enforcement of Foreign Arbitral Awards issued on 10 April 1987 and the Notice on the Implementation of Chinese-Foreign Agreements on Judicial Assistance issued on 1 February 1988, for instance, require the competent Chinese courts to conscientiously study the international treaties concerned and, when receiving applications or requests for judicial assistance, to handle the matter in question strictly in conformity with the provisions of these treaties concluded or acceded to by China. ${ }^{63}$ On 13 May 1989, the People's Supreme Court issued another Notice, to clarify the scope of cases that the Chinese admiralty courts are competent to file for trial. According to this Notice, these cases include, inter alia, applications filed under the 1958 New York Convention and those for judicial assistance under the other agreements on judicial assistance concluded by China. ${ }^{64}$

In accordance with China's policy of opening to the outside world, the number of cases involving the direct application of treaties in the Chinese

\footnotetext{
${ }^{62}$ The Treaties on judicial assistance have been concluded with Poland (1988), France (1988), Mongolia (1990), Romania (1993), Russia (1993), Byelorussia (1993), Ukraine (1994), Cuba (1994), and Spain (1994). Among these treaties, those with Poland, Mongolia, Romania, Russia, Byelorussia, Ukraine, and Cuba deal with both civil and criminal matters, whereas the other treaties deal with civil and commercial matters only. Moreover, a number of bilateral treaties on judicial assistance between China and other states have been signed or initialed.

${ }^{63}$ For the former notice, see, Zhongguo Falü Nianjian [Chinese Yearbook of Law] 1989 (Beijing, Falü Chuban She), at 548; the latter one was documented as Doc.(1988)Fa(ban) Fa No. 3. The People's Supreme Court is the highest judicial organ in China. One of its main tasks is to supervise the work of the subordinate courts by providing them with judicial guidance and interpretations through the form of notices.

64 Zhonghua Remin Gongheguo Falü Guifanxing Jieshi Jicheng [Collection of Regulated Interpretations of the Laws of the PRC] (Changchun: Jilin Remin Chuban She, 1990) at 1041.
} 
municipal legal order is steadily increasing. The Supreme People's Court has repeatedly stated in its annual reports to the NPC in recent years that cases involving foreign interests must be handled by the Chinese courts strictly in conformity with the treaties concluded or acceded to by China. The following case is an example of the direct application of the 1929 Warsaw Convention for the Unification of Certain Rules relating to International Carriage by Air by a Chinese court in dealing with damage arising out of theft during international air carriage. ${ }^{65}$

A Belgium-based diamond company filed a law suit against the Beijingregistered agent of a Chinese air carrier for compensation for stolen goods. ${ }^{66}$ Under a contract for the sale of a certain amount of rough diamonds, the plaintiff had shipped the goods in question to the Shanghai-based buyer through an international air carrier. While in the care of the defendant prior to their delivery to the buyer, they were stolen by an employee of the defendant. Before the Chinese court, the parties agreed on the defendant's liability for the resulting damage. The dispute was over whether this liability was limited to the declared value of the stolen diamonds in light of Art. 22 of the 1929 Warsaw Convention or unlimited under Art. 25 of the 1955 Hague Protocol for the Amendment of the Warsaw Convention. ${ }^{67}$ During the proceedings, each of the parties invoked either of the two international conventions. In the end, the Court ruled that the plaintiff had failed to show that the theft committed by the defendant's employee was an act within the scope of his employment. The Court thereby denied the plaintiff's claim that Art. 25 of the Hague Protocol be the governing law, and decided that Art. $22(2, d)$ of the Warsaw Convention was to be applied instead. As a result, the defendant was held liable and convicted to pay damages as assessed by the value declared by the plaintiff in the airway bill of lading. ${ }^{68}$

\footnotetext{
${ }^{65}$ For an English summary of this case, see 6 China Law \& Practice (1992) No. 8.

${ }^{66}$ The law suit was filed with the Beijing Municipal Intermediate People's Court which, according to the PRC Civil Procedure Law, is the court of first instance in foreign-related economic dispute cases.

${ }^{67}$ China acceded to the 1929 Warsaw Convention in 1958 and to the Hague Protocol in 1975. According to Article 22 of the Convention, an agent of a carrier is liable to pay damages of which the sum should not exceed that of the declared value. However, Article 25 of the Protocol provides that there shall be no limit to the liability for a carrier's employee or agent if the damage resulted from an act or omission taking place with intent to cause damage or recklessly, and with knowledge that damage would probably result, and if the employee was acting within the scope of his employment when committing the act or omission.

${ }^{68}$ As no party appealed, this decision of the court became definitive. The case does not reveal the reasons why the court applied the Convention.
} 
The absence of enabling provisions does not, however, necessarily bar treaties from being directly applied. When dealing with the Chinese practice one should bear in mind that it is not until one and a half decade ago that allout efforts to rebuild a modern legal system in China started to be made. At the time of enactment of new law the Chinese legislative authorities, due to lack of experience and pressure of time, often do not envisage the necessity of taking the issue of direct application of treaties into account. Yet the question has become increasingly prominent, mainly because of the rapid expansion of China's treaty relations in recent years, coupled with the rise of new circumstances. This is particularly the case in the field of criminal law. In recent years, there has been a sharp increase in China of offences involving international elements, such as drug trafficking, terrorism, smuggling illegal immigrants, etc. In order to enhance international cooperation in fighting these transboundary crimes, China has acceded to a number of multilateral treaties which require the parties to exercise jurisdiction in the municipal sphere over certain, specified, offences. Moreover, China has concluded a number of bilateral treaties on judicial assistance for criminal matters. Yet the PRC Criminal Law (Penal Code) and the Criminal Procedure Law lack provisions enabling the Chinese authorities to directly apply these treaties in the Chinese municipal sphere. Therefore, questions relating to the direct application of these treaties have to be addressed through policy guidance and supplementary legislative acts. ${ }^{69}$

For example, on 19 December 1985 AlimURAdov ShAMIL GADJI OGLY, a Soviet co-pilot, hijacked an airliner in flight in Soviet air space and forced it to land in Heilongjiang province in China. The hijacker was arrested by the Chinese authorities. When instituting criminal charges against him the InterMediate People's Court of Harbin was apparently confronted with the absence in the Chinese Criminal Law of relevant provisions on the crime of hijacking, as well as provisions authorizing the Court to directly apply the provisions of treaties to which China was a party. Under these circumstances, the Chinese court sought policy guidance from the Chinese government. It referred to China's accession to the three international conventions on the safety of civil aviation $^{70}$ and to the policy statement which the State Council had made upon China's accession in the form of a Notice. The Notice directed that in case a

\footnotetext{
${ }^{69}$ The vague term 'policy guidance' is my own. It refers to anything short of formally enacted and promulgated legal rules, including internal rules formulated by competent authorities for their internal use in dealing with various practical matters. These internal rules form a phenomenal aspect of the present Chinese legal system.

${ }^{70}$ China acceded to the 1963 Tokyo Convention in 1978, and to the 1970 Hague Convention and 1971 Montreal Convention in 1980.
} 
hijacked foreign airplane lands on Chinese territory, the case be duly handled according to the relevant provisions of the Conventions and in conformity with the Chinese municipal law. ${ }^{71}$ Although lacking formal legislative character, this Notice was read in conjunction with Article 3(1) of the Criminal Law, which prescribes: "The present law shall apply to all crimes committed within the territory of the People's Republic of China." As a result the Intermediate People's Court of Harbin found itself competent to try the case. It thereby decided that the unlawful and violent seizure of the aircraft in question and its subsequent forced landing on Chinese territory constituted a criminal offence under the international conventions and the Chinese Criminal Law. ${ }^{72}$ As a result of this finding, the court sentenced the Soviet defendant to eight-year imprisonment, which was later upheld by the Supreme People's Court. ${ }^{73}$

In order to effectively and efficiently handle such internationally defined offences, the Chinese government decided to take ad hoc supplementary legislative action enabling the Chinese authorities to directly apply treaties in criminal proceedings. Thus the Standing Committee of the NPC adopted a decision on 23 June 1987, declaring that China would, "within the scope of its treaty obligations, exercise criminal jurisdiction over the crimes prescribed by international treaties concluded or acceded to by the People's Republic of China." 74 Attached to this decision were the international treaties in question. $^{75}$ It is clear that this decision was meant to supplement the PRC Criminal Law and to provide a more formal legal basis for the Chinese authorities in establishing jurisdiction over the crimes prescribed by direct

\footnotetext{
${ }^{71}$ MA SHOUREN (ed.), Zhongguo Jinnian Shewai She Gang Ao Anjian [Recent Cases Involving Foreign Elements, Hong Kong and Maccao] (Beijing: Zhongguo Chengshi Jingji Shehui Chuban She, 1990) at 28.

72 Article 79 of the PRC Criminal Law provides: "A crime not specifically prescribed under the specific provisions of the present law may be confirmed a crime and sentence rendered in light of the most analogous article under the specific provisions of the present law; provided however, that the case shall be submitted to the Supreme People's Court for its approval".

${ }^{73}$ MA SHOUREN, supra $\mathrm{n} .70$, at 29.

${ }^{74}$ Article 67(3) of the Constitution empowers the Standing Committee to partially supplement as well as amend laws enacted by the National People's Congress when the latter is not in session. ${ }^{75}$ They are: the 1973 Convention on the Prevention and Punishment of Crimes against Internationally Protected Persons including Diplomatic Agents, the 1970 Convention for the Suppression of Unlawful Seizure of Aircraft, the 1971 Convention for the Suppression of Unlawful Acts against Safety of Civil Aviation, the 1980 Convention on the Physical Protection of Nuclear Materials and the 1979 Convention against the Taking of Hostages. In view of the decision of the Standing Committee to ratify the 1988 Convention on Suppression of Unlawful Acts against the Safety of Maritime Navigation and the 1988 Protocol for the Suppression of Unlawful Acts against the Safety of Fixed Platforms Located on the Continental Shelf, these two treaties should also be added to the list.
} 
reference to treaty provisions. As explained by the Premier of the State Council, when requesting the Standing Committee of the NPC to adopt the above decision:

"In order to combine systematically China's international obligations under this kind of treaties concluded or acceded to by our country with the provisions of China's municipal law and before adjustment is made to the provisions concerning the scope of our present criminal law, the State Council views it necessary to request the Standing Committee of the NPC to decide that the People's Republic of China will regard the crimes prescribed by the international treaties which it concludes or accedes to as crimes under its municipal law, and will exercise criminal jurisdiction over these crimes within the scope of its obligations." 76

It is noteworthy that to this date, certain criminal offences such as terrorism and hijacking have not yet been included in the PRC Criminal Law. However, the above decision of the NPC Standing Committee enables the Chinese authorities to establish criminal jurisdiction by direct reference to the relevant treaty provisions, and to convict and sentence the offenders in conformity with the most analogous provisions of the Criminal Law.

It thus appears that, even though not all statutes have enabling provisions allowing the direct application of treaties, policy guidance from the government and supplementary legislative acts play an important role in filling the gap. In the absence of a supplementary legislative instrument the role of policy guidance becomes more prominent.

When China acceded to the 1961 Vienna Convention on Diplomatic Relations and the 1963 Vienna Convention on Consular Relations there was no legislative act to incorporate these two treaties into the Chinese municipal legal system, let alone enabling provisions permitting the municipal authorities to directly apply the treaty provisions. ${ }^{77}$ Several years later the Chinese courts were able to directly apply certain provisions of the two conventions by virtue of Article 188 of the 1982 Civil Procedure Law (for Trial Implementation) ${ }^{78}$. However, direct application by virtue of this article was confined to civil

\footnotetext{
${ }^{76}$ Remin Ribao [People's Daily], 17 June 1987, translated by this author.

${ }^{n}$ China acceded to the Vienna Convention on Diplomatic Relations in 1975 and to the Vienna Convention on Consular Relations in 1979.

${ }^{78}$ Article 188 provided: "In the event of civil lawsuits brought against foreign nationals, foreign organizations or international organizations that enjoy judicial immunity, the People's Court shall deal with them according to the laws of the People's Republic of China and any international treaties concluded or acceded to by China". The Laws of the People's Republic of China 19791982, supra $\mathrm{n} .55$ at 291.
} 
lawsuits filed against foreign nationals, foreign organizations, or international agencies enjoying judicial immunity. Other cases involving diplomatic or consular privileges and immunities as provided for in the two Conventions remained to be handled under the policy guidance of the Supreme People's Court.

In 1985, the High People's Court of Shanghai had to request instructions from the Supreme People's Court in regard to whether the counsellor of the Swiss Embassy to China could in his official capacity hire Chinese lawyers to represent citizens of Switzerland in civil litigations in China. The Supreme People's Court replied: "Upon our studies, we consider that, in the light of the relevant provisions of the Vienna Convention on Diplomatic Relations and those of the Vienna Convention on Consular Relations to which China has acceded, it is within the scope of its official function that the Swiss Embassy to China can, upon the request of Li Meiti and Li Aiwei, citizens of Switzerland, hire lawyers on their behalf." 79 Under this guidance of the Supreme People's Court, the High People's Court of Shanghai thereupon applied the relevant provisions of the two Conventions to this case.

The rapid growth and development of civil and economic transactions between Chinese and foreign parties since the early 1980s have apparently rendered practices like these out of date. A more normative and efficient way to deal with such cases was badly needed, calling for legislative acts which incorporate the provisions of the conventions into the Chinese municipal system so that the competent Chinese authorities could in each specific case refer to them without delay. Hence, the Standing Committee of the NPC decided to enact the PRC Regulations for Diplomatic Privileges and Immunities and the PRC Regulations for Consular Privileges and Immunities, in 1986 and 1990 respectively. These two statutes contain provisions identical with the provisions concerned in the Vienna Conventions in every aspect ${ }^{80}$ and, besides, reflect the Chinese practice in implementing the two Conventions. They both provide, for instance, that persons enjoying diplomatic or consular privileges and immunities shall not intervene in China's internal affairs. Even where the two statutes do not contain provisions conflicting with the Vienna Conventions, they still expressly state that the provisions of treaties concluded or acceded to by China shall prevail if they are found to differ from

\footnotetext{
${ }^{79}$ Zhonghua Renmin Gongheguo Falü Guifanxing Jieshi Jicheng, supra n. 64, at 1066.

${ }^{80}$ The two statutes, as indicated by their titles, only deal with a part of the two Vienna Conventions, namely, the diplomatic and consular privileges and immunities.
} 
those of the two statutes. ${ }^{81}$ These enabling provisions are intended to "clarify the relationship" between the two statutes and the relevant parts of the two Vienna Conventions. ${ }^{82}$

Given the conspicuous silence of the Constitution and the lack of a general legislative regulation, it follows that, under the present Chinese system, the question of direct application of treaties is addressed generally by enabling provisions in statutes dealing with various subject matters of Chinese municipal law. Viewed from a formal legal perspective, such statutes act as the threshold to the direct applicability of treaties. From a substantive perspective, directly applicable treaty rules are thus confined to those relating to relations, interests, or activities occuring within the municipal legal sphere and within the normal scope of competence of the Chinese judicial and administrative authorities, and consequently providing sufficient cause of action under municipal law.

Thus, on a statute-by-statute basis, direct application of treaty rules is predicated on the following factors: (1) the treaty regulates a subject matter of the municipal legal sphere and provides the municipal legal subjects with a cause of action; (2) a statute contains an enabling provision permitting the municipal authorities to directly apply the treaty rules or, or lacking such provision, the existence of policy guidance or supplementary legislative acts having the same effect; (3) this permission is based on either the existence of a discrepancy between the treaty and municipal rules, or on the yielding of the subject matter to the authority of treaty law; (4) the treaty rule possesses mandatory quality in determining justiciable rights and obligations, as measured against the conflicting municipal law rule or, as the case may be, the corresponding rule in the yielding municipal law.

The dependence on an enabling clause or, for that matter, policy guidance, eventually coupled with supplementary legislative acts, introduces delay and uncertainty. Treaty rules might not be directly applied, however directly applicable they may be in terms of their mandatory quality. This is particularly the case in regard to treaties on human rights. ${ }^{83}$

\footnotetext{
${ }^{81}$ Noticeably, the Regulations for Consular Privileges and Immunities provides in Article 27(2): "Matters concerning consular privileges and immunities provided for differently in bilateral treaties or agreements which China has concluded with foreign countries shall be handled in accordance with such treaties and agreements".

${ }^{82}$ Remin Ribao [People's Daily], 28 August 1986.

${ }^{83}$ LI ZHAOJIE, 'Cultural Relativity and the Role of Domestic Courts in the Enforcement of International Human Rights: a Survey of the Practice and Problems in China', paper to be published in the Proceedings of the International Symposium on the Role of Domestic Courts in
} 
From a strictly legal perspective, the direct applicability of a municipally valid treaty rule should be restricted only by the competence of the relevant municipal authorities as set out by the Constitution and legislative instruments on the one hand, ${ }^{84}$ and by the mandatory quality of the said treaty rule on the other. This view, however, is as yet incompatible with the present state of development of the Chinese municipal legal system (particularly the conspicuous silence of the Constitution), the limited experience of the judicial and administrative authorities in applying treaties, and the stereotyped mindset which recognizes the desirability of the municipal application of international treaties only when foreign interests are involved. ${ }^{85}$ Thus the Chinese system is not quite 'international-law-friendly' from a strictly legal point of view. What really matters in this regard, however, is that the approach employed to distinguish between directly applicable treaties and indirectly applicable ones should not constitute a denial of the legally binding force of international treaties. The Chinese method of giving effect to a treaty in the municipal legal order should not compromise the legal obligations assumed under the treaty; refusal to implement a treaty on the ground of its indirect applicability in the municipal sphere would give rise to state responsibility for the breach of international obligations. Thus, if a treaty can not be directly applied due to the lack of mandatory quality, absence of a statutory enabling provision, or absence of legislative supplementation and policy guidance, the Chinese state is internationally obliged to take legislative and administrative acts either to enact new legislation or to adjust existing laws in order to give effect to the treaty. Unless, of course, the existing municipal law is already fully adequate for the implementation of the non-directly applicable treaty. In these circum-

\footnotetext{
Adjudication of International Human Rights (held in Italy under the auspices of the University of Siena, 21 to 22 June 1993).

${ }^{84}$ Article 12 of the PRC Administrative Procedure Law provides:

"The people's courts shall not accept and hear cases instituted by citizens, legal persons or other organizations with regard to the following matters:

1. acts of state relating to such matters as national defense and diplomatic affairs; [ . . .]"

This article delineates the competence of the Chinese courts in adjudicating administrative matters. Thus, if a treaty to which China is a party deals with these matters, it does not fall within the competence of a Chinese court on direct application, no matter how precise its wording might be. ${ }^{85}$ The phrase 'foreign interest' is a jargon of Chinese jurisprudence, denoting foreign-related legal relations, in which either the parties to the transaction are foreign nationals or stateless persons or the subject matter of the transaction involves foreign interests, such as a contract executed in a foreign country, property belonging to foreign nationals or situated in a foreign country, etc. The provisions of the Civil Procedure Law, the General Principles of Civil Law and the Administrative Procedure Law which allow the application of treaties are all contained in a special chapter dealing with legal proceedings involving foreign elements.
} 
stances, the adherence to the treaty obligations is embodied in the enforcement of the municipal law.

A typical example of adopting new legislation to give effect to an indirectly applicable treaty is China's response to Article 6(5) of the 1980 Sino-American Agreement on Trade Relations. This provision reads:

"Both Contracting Parties agree that each Party shall take appropriate measures, under its laws and regulations, to ensure to legal or natural persons of the other Party protection of copyrights equivalent to the copyright protection correspondingly accorded by the other party". ${ }^{86}$

After the Agreement came into effect on 1 February 1980, the PRC State Administration of Publications issued its opinion about how to implement this part of the Agreement. The opinion stated:

\begin{abstract}
"The obligation that China assumes under this article was not to provide the immediate copyright protection for the publications [published] in the United States upon the [coming into] effect of this Agreement. Instead, China is obliged to take measures appropriate to the concrete circumstances in China to create conditions for the copyright protection upon the [coming into] effect of this Agreement, and to provide the copyright protection for the publications published in the United States according to the laws and regulations of China, when such conditions are mature [. . . W. We will invite foreign experts to give lectures on copyright law, sponsor copyright workshops, send people abroad to study copyright business, establish copyright research institutions, and draw up copyright legislation (or regulations). These are the 'appropriate measures' that we take [under this agreement]". ${ }^{87}$
\end{abstract}

This statement suggests that, while Article 6(5) has acquired validity within the Chinese municipal legal order (otherwise there would be no legal ground for taking measures [. . .] "to provide copyright protection for the publications published in the United States according to the laws and relations of China", it only sets out a general obligation for each party to take measures under its law and regulations to ensure the copyright protection without specifying what these 'measures' are. Apparently, this obligation lacks the mandatory quality or definiteness that is indispensable to provide a cause of action or to create rights justiciable within the scope of the competence of the Chinese authorities.

${ }^{86} 31$ US Treaties and Other International Agreements, Part 6, at 4658.

${ }^{87}$ Zhonghua Remin Gongheguo Falü Guifanxing Jieshi Jicheng, supra n. 64, at 562-563. 
The obligation which China assumed under this part of the Agreement is to enact new laws or to adjust its existing laws so far as necessary to give effect to the Agreement. In fact, since the Agreement came into force, China has adopted new copyright legislation. In 1990, the PRC Law on Copyright was promulgated and came into effect on 1 June $1991 .^{88}$ According to this statute, works published by a foreign person outside China shall be entitled to the copyright protection as required by the agreements between his or her country and China or by international treaties acceded to by both his or her country and China.

Upon its accession to the Berne Convention for the Protection of Literary and Artistic Works and the conclusion of bilateral copyright treaties ${ }^{89}$, the Chinese government decided to make adjustments to its copyright legislation in order to implement its international obligations. On 25 September 1992, the State Council promulgated the Regulations for the Implementation of International Copyright Treaties. ${ }^{90}$ These Regulations aimed at elevating the level of copyright protection accorded to foreign works as required by the minimum standards of the Berne Convention and by other bilateral copyright treaties. Many of the provisions prescribed by these Regulations are either absent from, or not clearly stipulated in, the existing copyright legislation. It is noteworthy that Article 19 of the Regulations reads: "If these Regulations contain provisions which differ from the international copyright treaties, the latter shall prevail". ${ }^{91}$ Thus, through this enabling provision, international treaties on copyright protection to which China is a party become directly applicable within the scope of the Regulations.

Another example of new legislation to give effect to a non-directly applicable treaty in the Chinese municipal sphere is the PRC Law for the Protection of the Rights and Interests of Women. On 29 September 1980, China ratified the Convention on the Elimination of All Forms of Discrimination against Women, which came into force for China on 4 December of the same year. Whereas the Convention had thereby become part of the Chinese municipal legal order, the obligation assumed under the Convention was to

\footnotetext{
${ }^{88}$ See 4 China Law \& Practice (1990) No.9 at 26-42. Subsequently the State Council enacted implementing rules and regulations for the protection of computer programs. See 5 China Law \& Practice (1991) No.6 at 28-40.

${ }^{89}$ This mainly refers to the 1992 Sino-US Protocol on the protection of US copyrights in China.

${ }^{90}$ These Regulations came into effect on 30 September 1992. See 6 China Law \& Practice (1992) No.10, at 6.

${ }^{91}$ According to Article 3, the term, 'international copyright treaties' refers to the Berne Convention and other bilateral copyrights agreements concluded by China.
} 
"take all appropriate measures" to progressively eliminate all forms of discrimination against women. In order to fulfill such an apparently non-directly applicable treaty obligation, the Chinese government decided to, within a reasonable period of time, enact a new statute and adjust its institutions so far as necessary to give effect to the Convention.

In 1990, the State Council established a Working Committee on Women and Children, in order to coordinate and push forward the government institutions concerned toward effectively safeguarding the rights and interests of women and children. Besides, in order to inform the public of the contents of the Convention, the Chinese government also disseminated hundreds of thousands of pamphlets containing the Chinese version of the Convention. ${ }^{92}$ Moreover, on 3 April 1992 the NPC adopted the PRC Law on the Protection of the Rights and Interests of Women, which entered into force six months later. This new legislation, which contains 54 articles, specifies women's rights ranging from equal participation in political and economic activities to education, work, property, marriage, family, and other personal interests which women should particularly enjoy. In formulating the text, the drafting committee paid close attention to China's international obligation under the Convention. In its statement to the NPC the drafting committee, among other things, noticed that: "China is under an international treaty obligation to adopt legislation for the protection of the rights and interests of women. As a socialist state, China must perform this obligation"..$^{93}$ Obviously, the term 'international treaty' referred to the above-mentioned Convention. The new legislation does not contain an enabling provision permitting the competent Chinese authorities to directly apply the Convention. By incorporating the provisions of the Convention into the statute, however, the municipal effect of the Convention has been ensured. ${ }^{94}$

An indirectly applicable treaty can also exert a strong impact on the interpretation and application of the existing municipal law. This is due to the assumption that a state does not intend to violate its treaty obligations. Thus, whenever it is possible to interpret the municipal law in accordance with a state's treaty obligations, the provisions of the treaty can serve as an interpretative aid.

\footnotetext{
${ }^{2}$ Remin Ribao [People's Daily], 11 October 1994 at 3.

${ }^{93}$ Fazhi Bao [The Law Daily], 10 April 1992.

${ }^{94}$ It is important to note that this statute, though formulated with reference to China's international obligation under the Convention, does not contain an enabling clause to apply treaties. This implies the intention of the Chinese government to keep matters of this nature completely within the domain of its municipal legal order.
} 
For example, let us assume that the aforesaid UN Convention on Torture is not directly applicable in the Chinese municipal legal order. In that case the relatively explicit definition of 'torture' under the Convention can have a strong impact on the interpretation of the relevant provisions of the Criminal Law and the Criminal Procedure Law, and thus contribute to keeping the Chinese municipal law in conformity with the Convention. The Convention thus also contributes to the awareness that the fight against torture and other cruel, inhuman or degrading treatment is required not only by the Chinese criminal law but also by international obligations under the Convention. This, coupled with the Chinese profession that China will keep its municipal law in line with the provisions of the treaty, will certainly provide victims of torture with much stronger arguments before the court. It is this author's opinion that in China the conferment of international law status to a value by way of its inclusion in a treaty testifies to the high degree of importance attached to that value. ${ }^{95}$

\subsection{Conflict between Treaties and Municipal Law}

As discussed earlier, under the Chinese system internationally valid treaties become automatically part of the Chinese municipal legal order. This implies that, when enacting new laws or concluding new treaties, China should take full account of the compatibility of its international treaties with its municipal law and try its best to keep them consistent with each other. In practice, however, the considerations underlying the two do not always coincide, resulting in conflict between the two branches of law. An example can be found in the 1988 Sino-French Agreement for Judicial Assistance in Civil and Commercial Matters. Article 20 of this Agreement provides:

"The request for recognition and enforcement of decisions rendered by the court of one Contracting Party shall be submitted directly by the party concerned to the court of the other Contracting Party".96

On the other hand, Articles 203 and 204 of the then Civil Procedure Law (for Trial Implementation) stipulated that judicial assistance could be provided only between a PRC court and a foreign court either on a treaty basis or in

\footnotetext{
${ }^{95}$ Li ZHAOJIE, supra $\mathrm{n} .83$.

${ }^{96}$ Chinese text in Zhonghua Renmin Gongheguo Guowuyuan Gongbao [Gazette of the State Council of the People's Republic of China], Vol. 8, No. 561, (15 April 1988), at 228-34. English translation in East Asian Executive Reports, December 1988, at 20-22.
} 
accordance with the principle of reciprocity. Apparently this provision precluded the litigating parties from directly seeking judicial assistance from a PRC court.

In solving a conflict between two municipal rules of law the generally followed doctrines are that the statute with a higher status in the hierarchy of the legal system prevails over the one with a lower status and, if the two rules belong to the same rank in the hierarchy, posteriori derogat priori should apply. When applying these doctrines to a conflict between a treaty and municipal law, however, special attention should be paid to the following two problems: As to the first doctrine, its operation presupposes the ranking of treaties in the municipal legal hierarchy. In some states, this question is regulated by the constitution. As to the second doctrine, a subsequently enacted municipal law may prevail over a previously concluded treaty, thus giving rise to state responsibility for the violation of an international obligation. ${ }^{97}$ To avoid this situation, the latter doctrine is often complemented by a fiction that law-makers do not intend to override treaty obligations by subsequent municipal law.

As indicated earlier, though for different purposes, China's practice in this regard is to give treaties a trumping effect over municipal law. Although the Constitution is silent on the matter, Article 67(14) provides that the Standing Committee of the NPC is empowered to decide on the ratification of 'treaties and important agreements' ${ }^{98}$ Under Article 7 of the PLCT, 'treaties and important agreements' include those that "contravene the laws of the People's

\footnotetext{
${ }^{97}$ In the Netherlands, the constitution requires the courts not to apply either prior or subsequent legislative provisions, including the constitution, if they conflict with self-executing provisions of international agreements. Art.55 of the 1958 French constitution provides: "Treaties or agreements duly ratified or approved shall, upon their publication, have authority superior to that of laws, subject, for each agreement, to its application by the other party". It is not clear whether, under Art.55, self-executing treaties would prevail over subsequent inconsistent legislation. The German and Italian constitutions provide that the general rules of international law take precedence over domestic law. In both countries, however, subsequent inconsistent laws prevail over prior international treaties. In the United States, the Restatement of the Law (Third) $\S 115$ states: "1. (a) An act of Congress supersedes an earlier rule of international law or a provision of an international agreement as law of the United States if the purpose of the act to supersede the earlier rule or provision is clear or if the act and the earlier rule or provision cannot be fairly reconciled. (b) That a rule of international law or a provision of an international agreement is superseded as domestic law does not relieve the United States of its international obligation or of the consequences of a violation of that obligation. 2. A provision of a treaty of the United States that becomes effective as law of the United States supersedes as domestic law any inconsistent preexisting provision of a law or treaty of the United States".
}

${ }^{98}$ Supra n. 17. 
Republic of China". Based on these two articles, all treaties which contain provisions differing from the laws of China must be submitted to the Standing Committee of the NPC for its decision on ratification. As treaty-making is part of the law-making powers of the Standing Committee, these treaties have the same rank as the law by which it is enacted within the Chinese municipal legal order: they are lower than the Constitution but higher than regulations and rules enacted by state organs of a lower rank than the NPC and its Standing Committee. At this level of the hierarchy, treaties are accorded supremacy over the conflicting provisions of statutes, and their trumping effect is not affected by the fact that they are concluded prior or subsequent to the conflicting statutes. The doctrine posteriori derogat priori, therefore, has no place in the Chinese system so far as the relationship between 'treaties and important agreements' and municipal law is concerned. ${ }^{99}$ In the abovementioned example of discrepancy between the 1988 Sino-French agreement and the PRC Civil Procedure Law (for Trial Implementation), Article 189 of the Law prescribed the trumping effect of treaties over conflicting municipal rules. As a result, Article 20 of the Sino-French Agreement prevailed over Articles 203 and 204 of the Law, though the former was formulated subsequent to the statute. ${ }^{100}$

\footnotetext{
${ }^{99}$ LI HAOPEI, supra $\mathrm{n}$. 5, at 395. A test case is China's attitude towards the law of the sea. In 1992, the NPC Standing Committee adopted the PRC Law on the Territorial Sea and Contiguous Zones. Article 6(2) of the Law provides: "Foreign ships for military purposes shall be subject to approval by the Government of the People's Republic of China for entering the territorial sea of the People's Republic of China". (translation by the Legislative Affairs Commission of the Standing Committee of the NPC, see 2AsYIL at 165). It was believed that this provision was the result of pressure from Chinese military circles. It raises the question of how China is to bring this municipal law regulation into line with the 1982 UN Law of the Sea Convention, which China may soon ratify. Under the UN Convention, ships of all States have the right of innocent passage; passage is considered innocent so long as it is not prejudicial to the peace, good order or security of the State; and such passage must be conducted in conformity with the other rules of international law. Accordingly, as a general rule, a coastal state has no right to require prior notification from or authorization for foreign warships passing through its territorial sea as a condition for innocent passage. Some Chinese scholars hold that the article should be revised if China finally decides to ratify the Convention, to the extent that it would not apply to the States parties to the Law of the Sea Convention. Note, however, that despite the rule in the UN Convention, about 40 of the 139 states which participated in the negotiation of the Convention prescribe the requirement of permission in their municipal laws as a condition for innocent passage for warships. See US Department of State, Office of the Geographer, National Maritime Claims: $1958-85$ (Geographic Research Study No. 20-21, Oct. 1985) at 9.

${ }^{100}$ Article 189 of the 1982 Civil Procedure Law (for Trial Implementation) provided: "If an international treaty concluded or acceded to by the People's Republic of China contains provisions differing from those found in this law, the provisions of the international treaty shall apply, unless the provisions are ones on which China has announced reservations". The Laws of the People's Republic of China 1979-1982, supra n. 55, at 291. The present PRC Civil Procedure Law has
} 


\section{INTERPRETATION OF TREATIES}

It is generally agreed that relevant rules as provided for in the 1969 Vienna Convention on the Law of Treaties should be equally followed in China for the interpretation of treaties. ${ }^{101}$ In case of application of a treaty in the municipal legal order, however, questions as to who has the authority to interpret and how the interpretation is to be carried out remain the discretion of the municipal legal system. ${ }^{102}$ While the question of application of treaties in the Chinese municipal system is related to the existence of a conflict between a treaty and the municipal law, the question of whether or not such conflict exists depends, to a large extent, upon how treaties are interpreted and by whom. Since no adequate data in this regard are available yet, ${ }^{103}$ this part of our inquiry will confine itself to look into some general principles on interpretation of laws in China, from which one may get some hints for the answer to our question.

As a general rule, the local people's courts in China have no competence to interpret the law which they apply. ${ }^{104}$ In accordance with the Law for the Organization of the People's Courts and the Decision on Strengthening the Work of Interpretation of Laws, which was adopted by the Standing Committee of the NPC in 1981, when a local people's court is faced with a situation that requires interpretation of a law, it must submit the question to the Supreme People's Court. The Supreme People's Court is the sole authority with competence to render interpretation of a legal rule for judicial proceedings. Such interpretation is aimed at, and limited to, how a legal rule or doctrine should be applied in a specific situation. This type of interpretation takes the form of judicial notice and has binding effect upon all the subordinate

added a provision which allows parties concerned to seek recognition and enforcement of a foreign judgment or arbitral award before a Chinese court. Article 267 provides: "If a legally effective judgment or ruling made by a foreign court requires recognition and execution by a People's Court of the People's Republic of China, the party concerned may directly apply for recognition and execution to the competent intermediate People's Court of the People's Republic of China".

101 WANG and WEI, supra $\mathrm{n} .5$, at 349.

${ }^{102}$ According to JACKSON, interpretation of international treaties by domestic authorities is far more common and in many cases more important than the interpretation by international tribunals. JACKSON, in: JACOBS and ROBERTS, supra $\mathrm{n}$. 4, at 164.

${ }^{103}$ Neither is enlightenment to be obtained from Chinese court decisions, since the courts usually give no legal reasoning of their judgments.

104 Wu DAYING and SHEN ZoNGling, Zhongguo Shehui Zhuyi Falü Jiben Lilun [Basic Theory of China's Socialist Legal System] (Beijing: Falü Chuban She, 1987) at 261. 
courts. If the law in question is a treaty, it should certainly be subject to the judicial interpretation by the Supreme People's Court.

When China acceded to the 1958 Convention on the Recognition and Enforcement of Foreign Arbitral Awards, it declared, in accordance with Article 1 of the Convention, that China will apply the treaty "only to differences arising out of legal relationships, whether contractual or not, which are considered as commercial under its national law". ${ }^{105}$ The Supreme People's Court in an earlier mentioned notice on the implementation of the Convention $^{106}$ rendered a detailed interpretation as to what constitutes "legal relationships, whether contractual or not, which are considered as commercial under its national law". According to this interpretation, the phrase refers to relationships implying economic rights and obligations arising from contracts or torts relating to certain subject areas, including:

\begin{abstract}
"sale of goods; lease of property; contractual projects and manufacturing; transfer of technology; equity joint ventures; cooperative joint ventures; exploration and exploitation of natural resources; insurance; credit and loan; labor service; agency; consultation service; transport of passengers and goods by sea, air, rail, and road; product liability; environmental pollution; maritime accidents; and ownership disputes, etc.; but not including disputes between foreign investors and the government of the host country"..$^{107}$
\end{abstract}

Apparently, it is difficult for a local court to apply the Convention to a given case without such a detailed interpretation.

Another type of interpretation under China's municipal legal system is characterized as legislative interpretation. This means that under the doctrine ejus est interpretari cujus est condere, when questions arise in regard to the purpose of a statute, the scope of its application, and the meaning of its provisions, the competency to interpret rests with those who have enacted the statute. Thus, if a treaty is ratified by the Standing Committee of the NPC, interpretation of that treaty falls within the power of the Standing Committee of the NPC to 'interpret statutes' as defined by Article 67 of the Constitution. By the same token, the State Council is empowered by Article 89 of the Constitution to interpret treaties it has approved. Such legislative interpretation has binding force not only for the judicial organs but also all other government institutions of China. As the legislative power of the Standing Committee of the NPC extends to "annul those administrative rules and regulations, decisions

\footnotetext{
${ }^{105}$ For the text of the Convention, see 21.3 TIAS, at 2518.

${ }^{106}$ Supra, text at n. 63.

${ }^{107}$ Zhonghua Remin Gongheguo Falü Guifanxing Jieshi Jicheng, supra n. 64, at 1027.
} 
or orders of the State Council that contravene the Constitution or the statutes", and to decisions on the ratification of treaties which contravene the laws of China according to Article 7 of the PLCT, ${ }^{108}$ the competence to decide on the existence of a conflict between a treaty and a municipal statute is certainly in the hands of the Standing Committee of the NPC.

\section{CONCLUSIONS}

The Chinese practice on dealing with the question of the effect of treaties in the municipal legal system is closely related to how best to solve the conflict between treaties and municipal law. As a Chinese official document states:

"Cases involving foreign elements shall be dealt with under the law of China so as to maintain China's sovereignty. Meanwhile, the provisions of multilateral and bilateral treaties concluded or acceded to by China shall also be strictly complied with. Where the municipal law and other internal rules come into conflict with China's treaty obligations, the provisions of treaties shall prevail. In the light of the general principles of international law, China shall not refuse to perform the obligations it assumes under international treaties. This [policy] is advantageous both to maintain China's prestige and to protect Chinese's citizens' interests abroad." 109

This being state policy, China attaches great importance to legal relationships which have acquired international character by virtue of a treaty and, consequently, the balance between treaty obligations and the municipal law is always tipped in favor of the former. This policy reflects China's attitude towards its international legal obligations in general. Such attitude finds its origin in China's long history. Indeed, Confucius himself once said some 2,500 years ago: "Of the three essentials, the greatest is good faith. Without revenue and without an army, a state can still exist, but it can not exist without good faith". ${ }^{110}$ China's present practice follows this historical legacy.

Beyond that, however, the Chinese practice is conducted within a rapidly growing but not yet fully-fledged municipal legal system. The PRC Constitu-

\footnotetext{
${ }^{108}$ See supra, text at nn. 39-40.

${ }^{109}$ Regulations on Certain Issues of Handling Cases Involving Foreign Elements, promulgated jointly by the Ministry of Foreign Affairs, the Supreme People's Court, the Supreme People's Procuratorate, the Ministry of Public Security, the Ministry of State Security, and the Ministry of Justice on 27 August 1987. See Zhonghua Remin Gongheguo Falü Guifanxing Jieshi Jicheng, supra n. 65 , at $1029-30$.

${ }^{110}$ WANG TIEYA, supra n. 5, at 315 .
} 
tion still abstains from prescribing the effect of treaties in the Chinese municipal legal order. From a strictly legal perspective, much has yet to be accomplished in order to achieve a more 'international-law-friendly' municipal law mechanism that puts the entire issue of implementing international treaty obligations under the rule of law. 